Japanese Yearbook on Business History - 1990/ 7

\title{
Business Activities of the Standard-Vacuum Oil Co. in Japan Prior to World War II
}

\author{
Takeo KIKKAWA
}

\section{STATEMENT OF THE PROBLEM}

This essay aims to consider the following seven points regarding the business activities of the Standard-Vacuum Oil Co. (hereafter, Stanvac) in Japan before World War II:

a) the reasons behind the direct entry into Japan of the Standard Oil Company of New York (hereafter, Socony) and Vacuum Oil;

b) the reasons why both companies successfully penetrated the Japanese market;

c) the reasons why Socony moved into oil production and refining in Japan, and why it withdrew from them;

d) the reasons why Socony allowed its position in the Japanese market to decline in the 1910s and 1920s;

e) the effects the merger of Socony and Vacuum had on business activities in Japan;

$f$ ) the effects the establishment of Stanvac had on business activities in Japan;

g) Stanvac's responses to the strengthening of national control over the petroleum industry in Japan after the enactment of the Petroleum Industry Law in 1934.

This essay will form one link in the operation of taking up typical 
foreign enterprises that have actually made a direct entry into Japan and expanded their business activities over a long period of time and adding a business-history study of them. The accumulation of materials from such a slow but steady operation has taken on an important significance in recent years, in the debate over "opening" of the Japanese market, given the opposition between those views that point out the substantial defects in foreign enterprises or foreign products, and those views that find fault with various unfair institutions existing in the Japanese market. I have already discussed in an earlier work the reasons why Stanvac and its predecessor companies fall under the designation "typical foreign enterprises that have made a direct entry into Japan and expanded their business activities over a long period of time," so I shall not go into this here. ${ }^{1}$

We can begin with a brief look at the history of Stanvac and its predecessors in Japan prior to the Pacific War. ${ }^{2}$ Vacuum Oil's Japan branch office and Socony's Japan branch office were opened in quick succession in 1892-93, and for many years they continued to hold a large share of sales in Japan, Vacuum Oil in the lubricating oil market, and Socony in the kerosene market. At the time of the opening of their Japan offices, Socony was an important constituent enterprise in the Standard Oil Group headed by John D. Rockefeller, and Vacuum Oil was also a Rockefeller subsidiary. As a result of the dissolution of the Standard Oil combine by the May 1911 U. S. Supreme Court decision, however, Socony and Vacuum came to go their own ways as independent enterprises. Before this happened Socony had already, in Novem-

${ }^{1}$ Takeo Kikkawa, "1934nen no Nihon no sekiyu gyōhō to Sutandādo Vakyūmu Oiru Kanpanī” [Japan's Petroleum Industry Law of 1934 and the Standard-Vacuum Oil Company] (1), Aoyama keiei ronsh $\bar{u}$ [Aoyama Journal of Business], vol. 23, no. 4, 1989, pp. 22-25.

${ }^{2}$ In this account of the history of Stanvac and its predecessors I am relying basically on Keiichi Tanaka's Sekiyu monogatari-Möbiru Sekiyu shöshi [The oil story: A short history of Mobil Oil Company], Mobil Sekiyu K. K., 1984. 
ber 1900, set up the International Oil Company, which had for a time entered the business of producing and refining oil in Japan. But in June 1907 and February 1911 Socony had sold International's assets to Nippon Oil Co. and withdrawn from the oil producing and refining business, to concentrate in Japan after that only on the selling of petroleum products.

Almost forty years after their opening of offices in Japan, Socony and Vacuum merged in July 1931 to form the Socony-Vacuum Corporation. Consequent upon this, in August 1932 the Japan offices of the two firms were united to form the Socony-Vacuum Japan Branch, but in September of 1933 this was once again reorganized into the Stanvac Japan Branch, when Socony-Vacuum and Standard Oil Company of New Jersey each financed half of the venture, with Socony-Vacuum providing its overseas sales organization and the latter its overseas production facilities (principally east of the Suez). Stanvac was to continue business activities in Japan from that time-even enduring unfavorable treatment under state control over the petroleum industry resulting from the 1934 Petroleum Industry Law (promulgated in March, enforced in July) - until it was forced to close the Japan office in December 1941 upon the start of the Pacific War.

Let me in passing mention a fine work dealing with the theme of this essay, The Standard-Vacuum Oil Company and United States East Asian Policy, 1933-1941, by Irvine H. Anderson, Jr (Princeton University Press, 1975). In circumstances that made the use of internal materials difficult, the author carefully gathered peripheral data from U.S. Department of State documents and other sources and consolidated the piecemeal historical facts that they revealed; it is literally a work of painstaking labor. Still, it remains true that Anderson's work is not completely satisfying from the point of view that this essay is taking, namely, a business-history study of the Stanvac Japan office and its predecessors. His work is strictly focussed on clarifying Stanvac's role in the drawing up of, deciding upon, and executing of the U. S. government's East Asian policy (more precisely, its anti-Japanese petroleum embargo policy) between the years 1933 and 1941; it does not put any priority on an 
analysis of the business activities, as such, of the Stanvac Japan office. As a result, Anderson's work disregarded several valuable bits of information telling about Stanvac activity in Japan that were to be found in data the author himself had managed to collect, and right from the beginning his study was not directed at the expansion of business in Japan on the part of Stanvac's predecessors.

Taking as my starting point, then, such previous studies, this essay will study Stanvac's predecessors and advance the argument by putting a priority on presenting as far as possible new facts and deepening our consideration of the seven points mentioned in the beginning, points that are considered important from a businesshistory point of view.

\section{DIRECT ENTRY INTO JAPAN}

Our first point is the reasons why Socony and Vacuum moved directly into Japan.

The usual explanation given is that Socony, which had been made responsible within the Standard Oil Group for exports to Asia, was adopting the direct sales method to replace the previous sale-on-consignment method so that it could counteract Russian kerosene, which had been coming into prominence in the Asian market, and that is why it opened a branch office in Japan. ${ }^{3}$ This explanation is not wrong as far as it goes, but there are two points that ought not be overlooked.

The first point, obvious as it may be, is that, while it can explain why Socony opened an office in Japan, it cannot explain why Vacuum did so. According to Keiichi Tanaka, chief editor in charge of compiling a history of Mobil Oil Company of Japan, ${ }^{4}$ there is a

${ }^{3}$ Thus, for example, Tōsuke Iguchi, Gendai Nihon sangyō hattatsu-shi II, sekiyu [History of the development of modern Japanese industries II, Petroleum], Kōjunsha, 1963, p. 92.

${ }^{4}$ Mobil Oil Company of Japan, along with Esso Oil Company of Japan, were the successors of Stanvac's Japan office when it was dissolved in 1962, and both companies still exist in Japan as Japanese juridical persons. 
strong possibility that Vacuum had already opened a branch office in Japan a step ahead of Socony, in 1892, and the reason it set the office up in Kobe at the time was that it considered the modern cotton spinning mills in the Osaka area as important sources of demand. ${ }^{5}$ In other words, unlike the case of Socony's Japan branch being opened because of the stimulus of supply-side circumstances (the competition with Russian kerosene), in the case of the opening of Vacuum's Japan branch the major operative force was demand-side circumstances (the sudden rise of the modern cotton spinning industry). ${ }^{6}$ And it is probably possible to say that the conditions for Vacuum to open a branch were more favorable in Japan than in China.

The second point is that the usual explanation in fact lumps together a whole chain of Asian branches opened by Socony and ignores the fact that Socony kept to a fixed program in opening branches. According to internal sources available in Mobil Corporation in the United States (the successor of Socony-Vacuum), ${ }^{7}$ Socony first opened a branch in China in 1892, then branches in India and Japan in 1893, to be followed by a wide network of branches in other Asian countries (Hong Kong and Java in 1894, British Malay in 1896, the Philippines in 1897, Taiwan in 1901, French Indo-China in 1905, and Turkey in 1909). ${ }^{8}$ The order in which these branches were opened no doubt faithfully reflects

${ }^{5}$ Cf. Möbiru Nihon [Mobil Japan], Mobil Sekiyu K.K., February-March 1989, p. 26.

${ }^{6}$ Tanaka writes that "Vacuum was especially positive about supplying special lubricating oil that would suit the requirements of its customers" (p. 57).

${ }^{7}$ File: Standard-Vacuum Oil Co.

${ }^{8}$ According to RG (Record Group Number) 256, Foreign Funds Control Papers, B (Box Number) 556, TFR-500 Original Reports, Series A II, Folder: Standard-Vacuum Oil Co. in the Washington National Records Center in Suitland, Maryland, other branches were also opened in Thailand in 1894, in Burma in 1906, and in Ceylon in 1909. However, it is impossible to determine whether these were Socony branches or Vacuum branches. 
which country's markets in the Asian scene were considered important by Socony at various times. It shows that, for Socony, as opposed to Vacuum, the heart of the Asian market was China, not Japan.

At any rate, what is certain is that one cannot advance the argument that Socony's opening of a branch in Japan was a quick response to Samuel Samuel \& Co.'s start of bulk export of Russian kerosene to Japan in 1893, that in other words Socony was only looking at trends in the Japanese market; ${ }^{9}$ one must develop the argument that Socony also had the whole Asian market in its sight.

\section{PENETRATION OF THE JAPANESE MARKET}

The second point to take up is that of the reasons why Socony and Vacuum succeeded in penetrating the Japanese market.

The reason why Vacuum penetrated the Japanese market is quite clear-cut. As already suggested, we can find the reason in the superiority of the quality of its products. ${ }^{10}$ On the other hand, regarding Socony's success in the Japanese market two points are raised in extant United States Department of State documents.

The first point is one expressed by J. C. Goold, general manager of Socony's Japan branch in 1928, who said that, because Socony had more efficient refining facilities than Japanese petroleum companies, its production costs were low and so it had strong competitive power even after transportation costs were added. ${ }^{11}$

If we put together the fact that in 1905 kerosene produced from domestic crude oil maintained a slight competitive advantage over imported kerosene because of the imposition of tariffs (it is believed this state of affairs was created by the 1904 tariff amend-

${ }^{9}$ See, for example, Nippon Oil Co., Nihon Sekiyu 100nenshi [100-year history of Nippon Oil], 1988, pp. 94-95.

${ }^{10}$ Tanaka, pp. 65, 67.

${ }^{11}$ Letter, Edwin L. Neville (U. S. Chargé d'Affaires as Interim, Tokyo) to the Secretary of State, June 21, 1928 (RG59, General Records of the Department of State, File Number 894.6363/29, in the National Archives, Washington, D.C.). 
ments), ${ }^{12}$ the fact that afterwards the relative price of domestic crude vis-a-vis imported crude rose and some Japanese petroleum companies began to engage in the refining of imported crude oil, and the fact that from the 1909 tariff amendments until the 1926 tariff amendments there was basically no difference between the tariffs on the import of crude oil and the import of petroleum products, ${ }^{13}$ then I suppose we could say the point is valid at least up to 1926.

The second point is one indicated by Joseph C. Grew, in 1931 U.S. Ambassador to Japan, who said that up to 1931 Socony's powerful distribution system gave it superiority over the Japanese oil companies. ${ }^{14}$ From what can be deduced from the file on the assets held by Stanvac as of 1941, a file included among GHQ/SCAP documents in the Washington National Records Center in Suitland, Maryland, ${ }^{15}$ it is clear that, in the period from the end of the Russo-Japanese War (1904-05) to World War I (1914-18), Socony had spread a network of oil tank plants throughout Japan (the year 1909 marked an important stage in the formation of this network of oil tank plants). ${ }^{16}$ At the time, the building of oil tank plants made possible the conversion from the previous import of kerosene in cans packed in cases to the low-cost import of bulkstorage kerosene; without this conversion, Socony would not have been able to win in its competition with Rising Sun Petroleum

12 Nippon Oil Co., p. 167.

${ }^{13}$ Kikkawa (1), p. 38.

${ }^{14}$ Letter, Joseph C. Grew to the Secretary of State, April 21, 1933 (RG59, 894.6363/32).

${ }^{15}$ SCAP, Civil Property Custodian, Foreign Property Division, United Nations Property Unit, "Claims-American Properties in Japan, 19461952" (RG331, B3813, 3822-3825, Folder: SVOC27-160).

${ }^{16}$ Because it is impossible to learn directly the year of establishment of the oil tank plants due to restrictions on the sources, here I have adopted the next best strategy of deducing circumstances relating to the establishment of oil tank plants owned by Stanvac at the outbreak of the Pacific War by noting the earliest year of acquisition of an asset entered in the register of assets of each oil tank plant. 
Company within Japan. Accordingly, I think it is safe to say that Socony built up its powerful distribution system in Japan in the period between the end of the Russo-Japanese War and World War I.

\section{ENTRY INTO AND WITHDRAWAL FROM OIL PRODUCTION AND REFINING}

Our third point is the reasons why Socony moved into oil production and refining in Japan, and why it withdrew from them. To put it another way, we want to examine here the details of the creation of International Oil in 1900 and the sale of its assets in 1907 and 1911.

As regards the creation of International Oil, the accepted argument points out that Socony, which transported kerosene in cans packed in cases from the east coast of the United States to Asia, was at a disadvantage both in transport distance and transport means, compared with Samuel Samuel \& Co. and other companies that transported Russian kerosene through the Suez Canal; that, in order to overcome these disadvantageous factors, throughout the 1890s Standard Oil tried hard to secure production and refining bases in various regions of the Pacific coast but did not succeed; that Standard Oil finally began a continuous operation of oil production and refining in California and Japan in 1900; that in Japan this took the form of the creation of International Oil by Socony; that an accelerating factor in the creation of International Oil was the amending of mining regulations in Japan in 1900 and the admissibility of foreigners' establishing mining companies with Japanese registration; and so on. ${ }^{17}$

Basically the argument is correct, but it leaves unanswered the question of why the Socony parent company so readily went along with the establishment of a large-scale company that was 8.3 times greater, in terms of authorized capital, than the largest Japanese oil company at the time, Nippon Oil (whose authorized capital at

${ }^{17}$ See, for example, Iguchi, pp. 95-105, and Tanaka, pp. 74-77. 
the time was $1,200,000$ yen, whereas International's came to $10,000,000$ yen), without looking into the matter sufficiently. Behind the fact that Julius W. Copmann, general manager of Socony's Japan branch, trusted the optimistic forecast of his friend, former Minister to Japan Edwin Dun, regarding Niigata crude oil, and the Socony parent company then accepted Copmann's proposal to establish International Oil, ${ }^{18}$ there is believed to lie the fact that Socony did not possess sufficient ability to gather and assess information about Japan's oil problems. At a later time, Saburō Kurusu, Chief of the Commercial Affairs Bureau of the Japanese Foreign Office, who negotiated with foreign oil companies in connection with the application of the Petroleum Industry Law, criticized Stanvac and Rising Sun in 1935 for not being well informed of Japan's oil situation and for neglecting to gather necessary information..$^{19}$ Apparently this sort of situation was a consistent pattern from a fairly early period on. ${ }^{20}$

As factors in the dissolution of International Oil, it should suffice to mention two points: a) crude oil production in Niigata and elsewhere in Japan did not show sufficient results; b) in contrast, Standard Oil's production and refining in California progressed smoothly.

By selling all of International Oil's assets, for which $6,500,000$ yen had been invested, to Nippon Oil for a mere $1,750,000$ yen, ${ }^{21}$ Socony naturally suffered a serious blow in its business activities in Japan. In 1907, when the first selling off of International Oil assets took place, Copmann departed from Japan as a way of accepting responsibility, and in his place H. E. Cole took up appointment as the second general manager of Socony's Japan branch..$^{22}$ Of the five general managers appointed before the Pacific War to So-

${ }^{18}$ Tanaka, pp. 75, 86-87.

${ }^{19}$ E. R. Dickover (U. S. Embassy, Tokyo), Memorandum, February 20, 1935 (RG59, 894.6363/181).

${ }^{20}$ Socony also had inaccurate knowledge of trends in oil tariffs in Japan in the latter half of the 1920s. On this, see Kikkawa (1), pp. 35-41.

21 Tanaka, p. 83.

22 Tanaka, p. 102. 
cony's, Socony-Vacuum's, and Stanvac's Japan branch, ${ }^{23}$ Cole was an exceptionally important figure, and he went on to be promoted to vice-president of the Socony head office. ${ }^{24}$ The sending of Cole can be interpreted as an expression of an unusual determination on the part of Socony to rebuild the Japan office. To rebuild the business in Japan, Cole poured his efforts into hastening the switch from imports of kerosene in cans packed in cases from eastern United States to the less expensive imports of bulk kerosene from California. The formation of a network of oil tank plants throughout Japan, in 1909 especially, was one response to Cole's policy. ${ }^{25}$

What must be noted here is the construction by Rising Sun of an oil refinery in Saitozaki in Fukuoka Prefecture in 1909, two years after Socony made the first sale of International Oil's assets. Rising Sun was a body formed in 1900, when Samuel Samuel \& Co.'s petroleum division became independent; as an individual enterprise under the umbrella of Asiatic Petroleum Company, ${ }^{26}$ which belonged to the Royal Dutch-Shell Group that was established shortly afterward, ${ }^{27}$ it was in the process of shifting weight from the import of Russian kerosene to the import of Dutch East Indies kerosene. The construction of the Saitozaki refinery is said to be due to an order from Shell's leader, Henri Deterding, who

${ }^{23}$ The general managers of Socony's Japan branch were Copmann, 1893-1907 (until 1905 his title was "agent"); Cole, 1907-14; H. A. Ensworth, 1914-26; and Goold, 1926-32. Goold also was Socony-Vacuum's general manager from 1932 to 1933, and Stanvac's from 1933 to 1936. Goold's successor as general manager of Stanvac's Japan branch from 1936 to 1941 was C. E. Meyer.

${ }^{24}$ Letter, H. A. Ensworth to H. E. Cole, June 3, 1927 (Rockefeller Family Archives, RG2 [OMR] Friends \& Services, B59, in Rockefeller Archive Center, North Tarrytown, New York).

${ }^{25}$ Tanaka, pp. 102-105.

${ }^{26}$ The "British-Dutch Agreement" was formed in 1901, and the complete merger of Royal Dutch and Shell Transport and Trading took place in 1907.

${ }^{27}$ Asiatic was established in 1903. 
visited Japan in 1908, but when one considers the situation at the time, when the profitability in tariff terms of importing crude oil as opposed to importing petroleum products was being lost as a result of the levying of additional tariffs on crude oil, it can only be called a poor decision. Apparently Rising Sun's management opposed Deterding's policy, but the story goes that they were in turn attacked by Deterding for not having taken advantage of conditions existing since 1904, under which the tariff on crude oil imports was lighter than that on the import of petroleum products. Rising Sun's Saitozaki refinery, completed in 1909, finally suspended operations in 1915 after a few occasions when imported crude treatment came to a standstill. ${ }^{28}$ In the case of Rising Sun, as in the case of Socony, there clearly was a mistake in judgment regarding the building of refineries within Japan.

The fact that the refineries built in Japan by both Socony and Rising Sun ended in a loss is believed to have left a "legacy of defeat" to later management activity in both companies. Despite the fact that the 1926 tariff amendments once again produced a lighter levy on crude oil than on petroleum products, Socony and Rising Sun showed no interest until 1931 in the building of refineries within the country, unlike Associated Oil Co., which did. One cause for this can surely be found in their common experience of loss from the building of refineries in the 1900 s.

\section{DECLINE IN POSITION IN THE 1910S AND 1920S}

We next turn our attention to the reasons why Socony allowed its position in the Japanese market to decline in the 1910s and 1920s. Since the very fact of this decline in position has been almost completely ignored in previous studies, it is necessary first to confirm the factual context.

In the 1900s competition between Rising Sun and Socony

${ }^{28}$ Shell Sekiyu K. K. [Shell Oil Co.], Sheru Sekiyu 60nen no ayumi [60 years of Shell Oil Co.'s progress], 1960, pp. 5-6; Iguchi, pp. 137, 141; Nippon Oil Co., p. 172. 
intensified when the former switched from importing Russian kerosene to importing Dutch East Indies kerosene, and the latter converted from importing case-packed cans of kerosene shipped from the east coast of the United States to importing bulk-storage kerosene shipped from California. Nonetheless, as can clearly be seen from the fact that, in the four-company agreement concluded in Japan in February 1910, ${ }^{29}$ Socony's and Rising Sun's shares of kerosene sales were set at $43 \%$ and $22 \%$, respectively, ${ }^{30}$ Socony held a higher position in the Japanese market in the late 1900s than did Rising Sun.

By the early 1930s, however, the positions of the two companies was reversed, as can be judged from each company's share of sales of various petroleum products in the Japanese market, as given in United States Department of State documents. ${ }^{31}$ Although Socony continued to surpass Rising Sun in the amount of kerosene sales in Japan (38\% of the share as against $20 \%$ ), in the important area of sales of gasoline, which by that time had replaced kerosene as the leading petroleum product, Socony's $24 \%$ share of gasoline sales lagged behind Rising Sun's 35\%. In previous studies the two foreign petroleum companies are treated as if they had occupied the top two positions in Japan's petroleum product market in a uniform and unchanging pattern, ${ }^{32}$ but in fact an important

${ }^{29}$ The parties to the four-company agreement were Socony, Rising Sun, Nippon Oil, and Hōden Oil.

${ }^{30}$ Sei Abe, "Kindai Nihon sekiyu sangyō no seisei hatten to Asano Sōichirō" [The formation and development of the modern Japanese petroleum industry and Söichirō Asano], Kigyō kenkyū nenpō [The Annual Bulletin of the Institute of Business Research] (Chūō University), no. 9, 1988, p. 179.

${ }^{31}$ Walter C. Teagle, Memorandum, August 21, 1934 (RG59, 894.6363/84).

32 See, for example, Sei Abe, "Dainiji taisenzen ni okeru Nihon sekiyu sangyō to Bei-Ei sekiyu shihon" [A study of the Japanese petroleum industry and British and American petroleum capital before World War II], in Shōgaku ronsan [The Journal of Commerce] (Chūō University), vol. 23, no. $4,1981$. 
change took place within the 1910s and 1920s, with a reversal of the relative positions of the two companies.

The first thing that comes to mind as a factor in Socony's decline is the effect of the Standard Oil Group dissolution in 1911. By the dissolution, Standard Oil Company of California (Socal) and Socony became mutual competitors, and the result was the possibility that obstacles might be created to Socony's exports to Japan, for Socony had been relying upon production bases in California. ${ }^{33}$ Still, that possibility is deemed to be small, for a number of reasons, among them being, first, the fact that Socal did not make any direct moves into Japan, hence it is difficult to see it as having any direct effect on Socony's exports to Japan; second, the fact that Socony bought up General Petroleum Corporation in 1926 and thereby secured production bases in California; ${ }^{34}$ and third and most persuasive, the fact that even in the early 1930s Socony was surpassing Rising Sun in kerosene sales in the Japanese market.

Rather, what needs to be noted here is the fact that, even though Socony ranked higher in kerosene sales, it lagged behind in gasoline sales. The amount of gasoline consumption in Japan exceeded the amount of kerosene consumption for the first time in $1926,{ }^{35}$ and within a short period after that the former had overwhelmed the latter. ${ }^{36}$ Table 1 was compiled from records of a court case in the United States relating to the merger of Socony and Vacuum; from the table we can see that Socony's key overseas sales regions were eastern and southern Asia, and that Japan (cont. on p. 45)

${ }^{33}$ In 1911 it was Socal, within the Standard Oil Group, that was in charge of all the operations in western United States.

${ }^{34}$ Tanaka, p. 109.

${ }^{35}$ Haruhito Takeda, "Nenryōkyoku sekiyu gyōsei zenshi" [A history of petroleum administration prior to the Fuel Bureau], Sangyō seisaku-shi kenkyü shiryö [Sources for research on the history of industrial policies], Sangyō Seisaku-shi Kenkyūjo, 1979, p. 180.

${ }^{36}$ See "Naichi sekiyu jukyō hyō" [Tables of Domestic Petroleum Demand and Supply], put out by the Fuel Bureau in Sekiyu gyōhō kankei shiryö [Materials Related to the Petroleum Industry Law], 1937, which is now kept in the Ministry of International Trade and Industry. 
Table 1. Foreign Sales of Various Products of Socony and Vacuum by Countries in 1929 (1)

(Unit: 1,000 barrels)

\begin{tabular}{|c|c|c|c|c|c|c|c|c|c|c|}
\hline \multirow{2}{*}{$\begin{array}{l}\text { COUNTRY, } \\
\text { TERRITORY }\end{array}$} & \multicolumn{2}{|c|}{ Kerosene } & \multicolumn{2}{|c|}{ Gasoline } & \multicolumn{2}{|c|}{$\begin{array}{c}\text { Fuel, Diesel } \\
\& \text { Gas Oils }\end{array}$} & \multicolumn{2}{|c|}{ Lubricants } & \multicolumn{2}{|c|}{ Misc. } \\
\hline & Socony & Vac & Socony & Vac & Socony & Vacuum & Socony & Vac & Soc & Vac \\
\hline United States (2) & 26,050 & 2,498 & 2,451 & 101 & 1,222 & 1,303 & 25,684 & 900 & 1,973 & 82 \\
\hline N. China (\& Manch.) & 157 & 0 & 1,799 & 0 & 103 & 17 & 345 & 0 & 95 & 0 \\
\hline South China & 49 & 0 & 461 & 0 & 14 & & 425 & 0 & 26 & 0 \\
\hline Indo-China & 28 & 0 & 178 & 0 & 7 & & 0 & 0 & 19 & 0 \\
\hline Siam & 13 & 0 & 53 & 0 & 5 & 87 & 0 & 0 & 4 & 0 \\
\hline Philippines & 222 & 0 & 216 & 0 & 18 & & 0 & 0 & 27 & 0 \\
\hline Dutch East Indies & 165 & 0 & 328 & 0 & 18 & & 10 & 0 & 88 & 0 \\
\hline Straits Settlements & 88 & 0 & 85 & 0 & 17 & & 90 & 0 & 18 & 0 \\
\hline Japan (Korea/Formosa) & 538 & 0 & 426 & 0 & 90 & 81 & 581 & 0 & 47 & 0 \\
\hline India (+ Arabia/Persia) & 7 & 0 & 1,647 & 0 & 245 & & 0 & 0 & 27 & 0 \\
\hline Burma & 0 & 0 & 24 & 0 & 7 & 84 & 0 & 0 & 10 & 0 \\
\hline Ceylon & 0 & 0 & 58 & 0 & 2 & $\therefore$ & 0 & 0 & 44 & 0 \\
\hline Bulgaria (3) & 21 & 0 & 62 & 0 & 11 & 0 & 41 & 0 & 0 & 0 \\
\hline Syria/Cyprus & 54 & 64 & 57 & 58 & 5 & 4 & 12 & 0 & 0 & 0 \\
\hline Greece & 153 & 0 & 109 & 0 & 20 & 6 & 213 & 0 & 3 & 0 \\
\hline Turkey & 112 & 0 & 143 & 0 & 19 & 2 & 559 & 0 & 2 & 0 \\
\hline Yugoslavia & 84 & 29 & 116 & 43 & 58 & 10 & 82 & 2 & 15 & 0 \\
\hline South Africa & 0 & 575 & 0 & 301 & 18 & 91 & 0 & 1 & 26 & 4 \\
\hline Australia & 0 & 2,109 & 0 & 463 & 33 & 169 & 0 & 0 & 1 & 59 \\
\hline Egypt/Sudan/Palestine & 0 & 180 & 0 & 591 & 0 & 35 & 553 & 68 & 0 & 0 \\
\hline Rumania & 0 & 0 & 0 & 0 & 0 & 10 & 0 & 0 & 0 & 0 \\
\hline Portugal (4) & 0 & 555 & 0 & 384 & 0 & 33 & 0 & 19 & 0 & 0 \\
\hline Spain & 0 & 0 & 0 & 0 & 0 & 32 & 0 & 0 & 0 & $\mathbf{0}$ \\
\hline Finland & 0 & 0 & 0 & 0 & 0 & 12 & 0 & 0 & 0 & 0 \\
\hline Italy & 0 & 0 & 0 & 0 & 0 & 96 & 0 & 0 & 0 & 1 \\
\hline France (5) & 0 & 0 & 0 & 0 & 0 & 332 & 0 & 0 & 0 & 1 \\
\hline Denmark & 0 & 0 & 0 & 0 & 0 & 30 & 0 & 0 & 0 & 0 \\
\hline Norway & 0 & 0 & 0 & 0 & 0 & 20 & 0 & 0 & 0 & 0 \\
\hline Sweden & 0 & 0 & 0 & 0 & 0 & 42 & 0 & 0 & 0 & 0 \\
\hline Germany & 0 & 0 & 0 & 0 & 0 & 160 & 0 & 0 & 0 & 0 \\
\hline England & 0 & 0 & 0 & 0 & 0 & 344 & 0 & 0 & 0 & 0 \\
\hline Hungary & 0 & 117 & 0 & 143 & 0 & 34 & 0 & 34 & 0 & 9 \\
\hline Poland & 0 & 42 & 0 & 62 & 0 & 32 & 0 & 65 & 0 & 17 \\
\hline Austria & 0 & 218 & 0 & 96 & 0 & 17 & 0 & 24 & 0 & 3 \\
\hline Czechoslovakia & 0 & 383 & 0 & 168 & 0 & 49 & 0 & 38 & 0 & 9 \\
\hline
\end{tabular}




\begin{tabular}{|c|c|c|c|c|c|c|c|c|c|c|}
\hline \multirow{2}{*}{$\begin{array}{r}\text { COUNTRY, } \\
\text { TERRITORY }\end{array}$} & \multicolumn{2}{|c|}{ Kerosene } & \multicolumn{2}{|c|}{ Gasoline } & \multicolumn{2}{|c|}{$\begin{array}{l}\text { Fuel, Diesel } \\
\text { \& Gas Oils }\end{array}$} & \multicolumn{2}{|c|}{ Lubricants } & \multicolumn{2}{|c|}{ Misc. } \\
\hline & Socony & Vac & Socony & Vac & Socony & Vacuum & Socony & Vac & Soc & Vac \\
\hline Gibraltar & 0 & 3 & 0 & 1 & 0 & 1 & 0 & 0 & 0 & 0 \\
\hline Canary Islands & 0 & 32 & 0 & 18 & 0 & 3 & 0 & 0 & 0 & 0 \\
\hline South America & 0 & 0 & 0 & 0 & 0 & 160 & 2 & 0 & 0 & 0 \\
\hline Mexico & 0 & 0 & 0 & 0 & 0 & 5 & 0 & 0 & 0 & 0 \\
\hline Canal Zone & 0 & 0 & 2 & 0 & 0 & 0 & 4 & 0 & 0 & 0 \\
\hline Canada & 33 & 0 & 0 & 0 & 1 & 91 & 24 & 4 & 0) & 1 \\
\hline Alaska & 0 & 0 & 0 & 0 & 0 & 0 & 105 & 0 & 0 & 0 \\
\hline Hawaii & 0 & 0 & 0 & 0 & 0 & 2 & 0 & 0 & 0 & 0 \\
\hline Others & 0 & 0 & 0 & 0 & 0 & 0 & 289 & 0 & 0 & 0 \\
\hline (Total, excluding U.S.) & 1,723 & 4,310 & 5,764 & 2,328 & 691 & 2,088 & 3,355 & 256 & 451 & 109 \\
\hline TOTAL & 27,773 & 6,808 & 8,215 & 2,429 & 1,913 & 3,390 & 29,018 & 1,155 & 2,424 & 191 \\
\hline
\end{tabular}

Notes: (1) Sales between companies have been eliminated from the business of the selling company, in order to avoid double counting. (2) Alaska and Hawaii are listed separately. (3) Vacuum sales are only nominal; they are reported under Yugoslavia. (4) Vacuum's sales include Morocco and West Coast Africa. (5) Vacuum's sales include Belgium, Holland, and Switzerland.

Source: District Court of the United States for the Eastern District of Missouri, United States of America (Petitioner), vs. Standard Oil Company of New Jersey et al. (Defendants); United States of America (Petitioner), vs. Standard Oil Company of New York and Vacuum Oil Company (Defendants), Vol. III, 1931, Government's Exhibit $1 \mathrm{~A}, 2 \mathrm{~A}$.

was an exceptional country in these two regions in that the demand for gasoline exceeded the demand for kerosene.

If we rely on Table 1 , the following two points stand out in regard to Socony's worldwide sales strategy in the 1910s and 1920s: a) from the mid-1910s, when gasoline demand in the United States exceeded kerosene demand, ${ }^{37}$ the heart of Socony's business activities was the sale of gasoline within the United States itself; b) but

${ }^{37}$ Tanaka, p. 93. 
in order to expand its gasoline sales in the United States smoothly, it was necessary to secure outlets for the kerosene that was produced simultaneously with gasoline in the United States refineries, and so Socony also emphasized its business activities in the Asian region, where demand for kerosene continued to exceed demand for gasoline.

In other words, for Socony in 1929, of all its overseas sales bases China and India, where the amounts of kerosene sales greatly exceeded gasoline sales, were markets whose strategic significance was clear, whereas Japan, where the amount of kerosene sales was less than gasoline sales, was a market whose strategic significance was uncertain.

The biggest cause of Socony's decline in the Japanese market in the 1910s and 1920s can be sought in the fact that Socony did not take sufficient measures in regard to the sale of gasoline, whose amount of consumption was increasing rapidly in Japan as a key product, because in its worldwide sales strategy Japan's position was unclear. What reveals this unequivocally is the slow start in opening gasoline stations in Japan. Socony is said to have opened the first modern-style gasoline stations, "service stations," in the United States around 1910..$^{38}$ According to a GHQ/SCAP document, however, the first service station was opened in Japan by Socony almost twenty years later, at the end of the 1920 s. $^{39}$ According to a Ministry of Commerce and Industry survey in 1928, the companies that overwhelmingly ranking top in the number of gasoline stations owned in Tokyo were Nippon Oil and Rising Sun. ${ }^{40}$

In contrast to Socony, for Asiatic Petroleum Co., which had its production base in the Dutch East Indies and expanded its business activities in the Pacific region, the strategic significance of selling gasoline in large amounts in Japan, one of the few countries in its business territory that was consuming large amounts of gasoline, was extremely clear. This explains why Rising Sun put

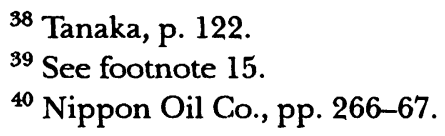


its energies into gasoline sales from early on, to go on through the 1910s and 1920s to surpass Socony and become the largest gasoline-selling company in the Japanese market. ${ }^{41}$

\section{THE MERGER OF SOCONY AND VACUUM}

Next we turn to our fifth point, the ways in which the merger of Socony and Vacuum influenced business activities in Japan. If I may put the conclusion first, the effects of the merger of Socony and Vacuum were not very great, compared to the effects of the formation of Stanvac (which we shall see in the next section).

As regards the merger of Socony and Vacuum, previous studies have stressed the fact that the businesses of both companies "joined in a position where they complemented each other." ${ }^{42}$ This much is true. Table 1 shows that Socony and Vacuum were quite clearly in a mutually complementary position in sales regions and products. A cause of slight concern is the fact that both companies were competing in the sale of lubricating oils in several countries, but even in these cases, as can be seen in Table 2, which shows the amount of lubricating oil sales, broken down by type of product, for each company in Japan in 1929, one can find a complementary relationship, with Vacuum's sales in high-grade products, and Socony's in ordinary-grade products.

Still, the accepted argument does not explain why Socony and Vacuum entered into a merger when they did, in 1931. The answer to this question may be sought in the fact that the two companies, both of which received blows from the worldwide panic, were able, by means of the unification of their organizations, to proceed with personnel retrenchment and the like, and to curtail expenses. According to a ledger to be found in Mobil Oil's head office in the United States, ${ }^{43}$ the forwarding price of Socony's export kerosene, which had been comparatively stable since 1922

\footnotetext{
${ }^{41}$ Kikkawa (1), pp. 23-24.

42 Tanaka, p. 135.

${ }^{43}$ Socony, Refinery Prices.
} 
Table 2. Sales of Lubricants in Japan by Socony and Vacuum according to Types of Oil in 1929

(Unit: barrels)

\begin{tabular}{r|r|r}
\hline TYPE OF OIL & SOCONY & VACUUM \\
\hline Premium motor oils & 1,228 & 14,069 \\
\hline Other motor oils & 8,533 & 1,223 \\
\hline Grease & 4,529 & 3,099 \\
\hline Transformer oils & 2,708 & 25,072 \\
\hline Marine oils & 130 & 10,807 \\
\hline Tanners oil & 0 & 264 \\
\hline Process oil & 4,406 & 0 \\
\hline Bineral sea, Absorb., Torch, \& Signal oils & 2,600 & 0 \\
\hline Base oils & 23,600 & 0 \\
\hline (A) Gargoyle special cylinder oils & 0 & 1,666 \\
\hline (B) Other cylinder oils & 3,381 & 1,245 \\
\hline (C) High-grade specialty machine engine oils & 3,301 & 11,258 \\
\hline (D) Other machine \& engine oils & 21,980 & 10,463 \\
\hline Sundries & 14,029 & 1,533 \\
\hline TOTAL & 90,425 & 80,699 \\
\hline
\end{tabular}

Notes: The price per gallon within the U.S. in 1929 was (A) 87107 cents; (B) 25-77 cents; (C) 50-107 cents; (D) 15-49 cents.

Source: Vol. III, Government's Exhibit 2B, in same source as Table 1 .

dropped sharply in 1930-31, under the influence of the worldwide panic. A letter kept in the Rockefeller Archive Center in the New York City suburb of North Tarrytown indicates that Socony-Vacuum achieved a cut in expenditures of $16.4 \%$ compared to the previous year by means of the merger. ${ }^{44}$ The same letter mentions

${ }^{44}$ Letter, C. E. Arnott to Thomas M. Debevoice, May 13, 1933 (RG2, Business Interests, B138, Folder: Socony-Vacuum Corporation). 
that within eighteen months after the merger a total of 4,316 people were retrenched in the overseas divisions of the two companies (113 were retrenched in Japan from the former Socony company alone).

Another interesting thing about the Socony-Vacuum merger is that overall the merger proceeded at Socony's pace, including the overseas division, where Vacuum was more powerful. This can be verified from another letter in the Rockefeller Archive Center; ${ }^{45}$ in it we find that the man appointed to be general manager of the Socony-Vacuum Japan branch that started up in August of 1932 was the general manager of the former Socony Japan branch, J. C. Goold.

\section{FORMATION OF STANVAC}

Our sixth point is the question of the influence on business activities in Japan of the formation of Stanvac. Unlike the merger of Socony and Vacuum, the formation of Standard-Vacuum Oil Company in September 1933 exerted a huge influence on business activities in Japan.

The initiative for the formation of Stanvac did not come from Socony-Vacuum but from Standard Oil (New Jersey). ${ }^{46}$ According to the memoirs of Evert J. Sadler, an executive of Standard Oil (New Jersey), Stanvac was born when Standard Oil (New Jersey) inherited the expansion of production of oil fields and refineries in the Dutch East Indies and, showing off its fresh entrance into the East Asian market, pressed Socony-Vacuum with the idea of the formation of a joint subsidiary, and the latter accepted the idea. ${ }^{47}$

${ }^{45}$ Letter, G. P. Whaley to Debevoice, June 14, 1932 (RG2, B138, Folder: Socony-Vacuum Corporation).

${ }^{46}$ Takeo Kikkawa, "1934nen no Nihon no sekiyu gyōhō to Sutandādo Vakyūmu Oiru Kanpanī” (3), Aoyama keiei ronshū, vol. 24, no. 3, 1989, pp. 54-59.

${ }^{47}$ Interviews/S. O. Co. (N. J.), Volume I, 1944-1945 (in Harvard University Baker Library, Boston), pp. 3-4. 
The formation of Stanvac was to make a great change, both quantitatively and qualitatively, in the significance of the Japanese market.

First of all, let us look at the change in the situation of the Japanese market in a quantitative sense. As can be gathered from Table 1, for Socony and Socony-Vacuum, which considered the United States as its key business region, and for Vacuum, which considered the United States and Europe as its key business regions, the Japanese market did not hold much weight. In contrast to this, for Stanvac, which carried out its business activities in overseas regions east of the Suez Canal and did not regard the United States or Europe as its business territory, the weight of the Japanese market can be described as fairly large. Table 3 , based on GHQ/SCAP documents, shows Stanvac's sales turnover in various countries for $1941 .{ }^{48}$ When studying this table one must take into consideration the fact that in June and August of this year the United States government implemented an embargo on oil exports to Japan. Making adjustments for this factor, one can consider the weight of the Japanese market to be quite large as far as Stanvac was concerned. Furthermore, according to a table in Anderson's book on the distribution of Stanvac sales in East and Southeast Asia in 1937 and 1939, the country that led China by a huge margin to occupy first place was none other than Japan. ${ }^{49}$

Next, as to the change in situation of the Japanese market in a qualitative sense, remember that for Socony and Socony-Vacuum Japan was a market that did not necessarily have clear strategic significance. With the formation of Stanvac, however, this changed completely. Stanvac's chief business regions were Asia and the Pacific, and, in contrast to Socony and Socony-Vacuum,

48 Unfortunately, since sources do not exist, it is impossible to know Stanvac's overall sales turnover for 1940 or earlier, broken down by countries.

${ }^{49}$ Irvine H. Anderson, Jr, The Standard-Vacuum Oil Company and United States East Asian Policy, 1933-1941 (Princeton University Press, 1975), p. 220. 
which were anxious to secure kerosene outlets, Stanvac was anxious to secure gasoline outlets. That Stanvac should accordingly look upon the Japanese market, where the demand for gasoline was exceptionally greater than anywhere else in Asia, as strategically important is; so to speak, only natural.

Table 3. Stanvac Sales in 1941 by Countries

(Unit: 1,000 barrels)

\begin{tabular}{l|r}
\hline COUNTRY OR TERRITORY & SALES \\
\hline Japan (incl. Korea/Taiwan/Manchuria) & 12,928 \\
\hline China (under Japanese occupation) & 14,366 \\
\hline China (non-occupied) & 2,580 \\
\hline Hong Kong & 6,729 \\
\hline French Indochina & 2,237 \\
\hline Philippines & 14,893 \\
\hline British Malaya (incl. Thailand) & 6,541 \\
\hline Burma & 778 \\
\hline India & 42,735 \\
\hline Ceylon & 2,339 \\
\hline South Africa & 40,440 \\
\hline Australia & 64,582 \\
\hline Dutch East Indies & 12,465 \\
\hline TOTAL & 223,613 \\
\hline
\end{tabular}

Note: These figures include only the sales of those branch offices and subsidiaries that dealt in petroleum products. In addition, in 1941 Stanvac had subsidiaries that dealt with crude oil production and refining (Dutch East Indies), petroleum exploration (Portugal), parts manufacturing and engineering (Australia), oil retailing (Hong Kong), and petroleum transport (Dutch East Indies, Canada, Panama). The Portuguese, Canadian, and Panamanian subsidiaries were founded in 1939, 1940, and 1938 , respectively.

Source: TFR-500 Original Reports, Series AII, Folder: Standard-Vacuum Oil Co. (RG265, B556). 
Further, the formation of Stanvac brought about a change in the petroleum product supply routes for the Japanese market. Socony, Vacuum, and Socony-Vacuum had mainly supplied the Japanese market with products produced in United States refineries, Stanvac, on the contrary, sent mainly products produced in Dutch East Indies refineries. What this meant, then, was that, by selling in Japan petroleum products imported from the the petroleum product supply routes for the Japanese market. Dutch East Indies, the Stanvac Japan branch stood in exactly the same position as Rising Sun. ${ }^{50}$

The change in the supply routes by Stanvac had an important influence on its management strategies in regard to the problem of Japan's petroleum controls. To discuss this point, it is first necessary to go back a little in time.

Through the tariff amendments of 1926 the tariffs levied on crude oil imports once again became lighter than those on petroleum product imports, with the result that it became more advantageous in Japan to import crude oil and refine it within the country, than to import petroleum products. ${ }^{51}$ The American oil company Associated took advantage of this situation and in 1929 entered a contract with Mitsubishi to establish a joint subsidiary, funded equally by both parties, to engage in importing and refining crude oil in Japan, and in 1931 the Mitsubishi Oil Co. was formed. Socony and Rising Sun, however, underrated the vitality of importing crude and refining it in Japan and until 1931 showed no interest in building refineries in Japan. ${ }^{52}$ Among the reasons for this, no doubt, can be given the fact that both companies were committed to refining in the places where the crude was produced, the fact that the aftereffects of the debacle of their refinery construction in Japan in the 1900s still remained, and the fact that

${ }^{50}$ Memorandum, S. P. Coleman to E. J. Sadler, August 6, 1940 (Henry J. Morgenthau, Jr's Diary, vol. 292, kept in the Franklin D. Roosevelt Library, Hyde Park, New York), pp. 268-70.

${ }^{51}$ Kikkawa (1), pp. 35-38.

52 Kikkawa (1), pp. 39-43. 
neither company was sufficiently well informed of movements afoot in the Japanese government in regard to oil tariffs. ${ }^{53}$

But as a result of the sudden fall in yen exchange after the export of gold was banned again in 1932 and another amendment of the oil tariffs in June of the same year, ${ }^{54}$ the profitability of refining imported crude over the importing of petroleum products became decisive (for example, in July 1933 the rate of import tariff on the retail price of bulk high-grade gasoline went as high as 19\%), ${ }^{55}$ and Socony-Vacuum and Rising Sun began seriously considering the building of refineries in Japan. ${ }^{56}$ If Socony-Vacuum and Rising Sun had built refineries in Japan in 1932, they might not have received unfair treatment in regard to quotas for petroleum product sales as a result of the 1934 Petroleum Industry Law, thanks to the principle of preference to domestic refining or if they did, it probably would have been at a reduced level. As a matter of fact, Mitsubishi Oil, 50\% funded by Associated, received exactly the same treatment as other oil companies engaged in domestic oil refining, and after the implementation of the Petroleum Industry Law it increased its sales share. ${ }^{57}$

As it turned out, however, Socony-Vacuum and Rising Sun did not build refineries in Japan. True, one factor existing for both companies was the fact that they could not receive sufficient guarantees about the future from the Japanese government, ${ }^{58}$ but for

${ }^{53}$ Kikkawa (1), pp. 35-41.

${ }^{54}$ Regarding the influence of the tariff amendments of 1932, see the second part of the Kikkawa article, in Aoyama keiei ronshü, vol. 24, no. 2, 1989, pp. 78-79.

55 Letter, S. V. Davis (Osaka District Sales Manager, Stanvac) to Howard Donovan (American Consul, Kobe), July 12, 1933 (RG84, U. S. Consulate General Correspondence, vol. 19, in the United States National Archives).

${ }^{56}$ Letter, H. W. Malcolm (Rising Sun) and J. C. Goold (Stanvac) to K. Nakajima (Minister of Commerce and Industry), November 29, 1932 (RG59, 894.6363/37).

57 Takeda, p. 227.

${ }^{58}$ Letter, Joseph C. Grew to the Secretary of State, April 21, 1933 (RG59, $894.6363 / 32)$. 
Socony-Vacuum a major influence on the decision was the formation of Stanvac. The reason is that the formation of Stanvac resulted in the Dutch East Indies once again becoming a supply source for petroleum products, and this made it less reasonable to build refineries in Japan. If Stanvac were to duplicate its assets in Dutch East Indies with refineries in Japan as well, it would probably find itself in difficulties about securing gasoline outlets. Following along the lines of thought of Walter C. Teagle, president of Standard Oil (New Jersey), which had originally owned Stanvac's production facilities in Dutch East Indies, in 1934 Stanvac abandoned the plan to build refineries in Japan ${ }^{59}$ In the same year Mitsui \& Co. and Rising Sun, which had each come up with its own proposals for building refineries in Japan in joint cooperation, also abandoned the idea after Stanvac did. ${ }^{60}$

The problem that arises here is, why was it that Asiatic (and its subsidiary, Rising Sun), which, like Stanvac, had production bases in Dutch East Indies, adopted a much more positive stance in regard to the building of refineries in Japan? Since I have been unable to make a sufficient study of sources in England and Holland, I am unable to give a satisfactory answer to this question at present, but perhaps the fact that Asiatic, unlike Stanvac, held reserves to export crude oil from Dutch East Indies to Japan may have been influential. ${ }^{61}$

As can be seen from the above, the formation of Stanvac can be considered to have had an extremely great influence on business activities in Japan. Still, previous studies of the history of the Japanese petroleum industry have hardly discussed the significance of Stanvac's formation at all. Despite the existence of organizational changes from Socony through Socony-Vacuum to Stanvac,

${ }^{59}$ Letter, Edwin L. Neville to the Secretary of State, September 21, 1934 (RG59, 894.6363/81).

${ }^{60}$ See Kikkawa (3), pp. 44-50, and part 4 of the same article in Aoyama keiei ronshü, vol. 24, no. 4, 1990, pp. 64-65.

${ }^{61}$ Memorandum, S. P. Coleman to E. J. Sadler, August 6, 1940 (Henry J. Morgenthau, Jr's Diary, vol. 292), pp. 268-70. 
the fact that most research works have used the single designation of "Standard" to cover them all attests very clearly to this fact. ${ }^{62}$

\section{RESPONSES AFTER ENACTMENT OF THE PETROLEUM INDUSTRY LAW}

Finally we come to the seventh point, which concerns the ways in which Stanvac responded to the strengthening of Japanese government regulation of the petroleum industry following the enactment of the Petroleum Industry Law in 1934. Since I am still publishing a detailed study of this matter in the Aoyama Gakuin University journal, Aoyama keiei ronsh $\bar{u}^{63}$ I shall limit myself to pointing out only the main points.

Regarding Stanvac's business activities under the Petroleum Industry Law, it is necessary to note the following two points. The first is that, in spite of Stanvac's and Rising Sun's strong resistance, their share of sales declined as a result of the unfair quotas on the amount of petroleum product sales..$^{64}$ The second is that both companies continued their business activities in Japan up to the start of the Pacific War in December 1941, without either of them having fulfilled the stockpiling requirement of the Law.

In previous historical studies Japanese researchers have, generally speaking, paid attention to the first point and stressed the loss of ground of the two foreign oil companies under the Law. ${ }^{65}$ For-

${ }^{62}$ Thus, Iguchi; Takeda; Tomio Noda "Senzenki nenryō kokusaku to Ei/Bei sekiyu shihon" [National fuel policy before World War II and British and American petroleum capital], Keieigaku kenkyu ronshü [Journal of Business Management Studies] (Seinan Gakuin University), no. 5, 1985; and Masaru Udagawa, "Senzen Nihon no kigyō keiei to gaishi-kei kigyō" [Business management and foreign-affiliated companies in Japan before World War II], 2 parts, in Keiei shirin [The Hosei Journal of Business], vol. 24, nos. 1, 2, 1987.

${ }^{63}$ Kikkawa (1), (2), (3), and (4) thus far.

64 Takeda, pp. 232-33.

${ }^{65}$ Iguchi, p. 256; Takeda, pp. 232-34; Abe (1981), pp. 201-02, 215-16; Tanaka, pp. 158-160; Noda, pp. 16-29; Udagawa (part 2), pp. 34-35. 
eign researchers, however, have put more weight on the second point and emphasized the effectiveness of the two foreign companies' resistance against the Law. ${ }^{66}$ The Japanese research, in that it has ignored the moves within the Japanese government aimed at compromise with the two foreign oil companies, manifested in the intensive negotiations of Shinji Yoshino, Vice Minister of Commerce and Industry, and Saburō Kurusu, Chief of the Commercial Affairs Bureau of the Foreign Office, with representatives of the foreign oil companies from January to April of 1935, as well as in the "Five-Point Memorandum" that resulted from these negotiations, has left a knotty problem ignored. On the other hand, the foreign researchers were unable, because they did not make use of Ministry of Commerce and Industry sources available in Japan, ${ }^{67}$ to enter into concrete details on the decline in the market share of the two foreign oil companies under the Petroleum Industry Law.

By means of the Law the Japanese government pursued the twofold task of aiming at an enlargement of the share of domestic oil refineries, entailing pressure on the two foreign oil companies, and at the same time forcing the latter, which were also important suppliers of heavy oils destined for use by the navy, ${ }^{68}$ to continue to import petroleum products. Skillfully using, depending on circumstances, the opposite stances taken by Stanvac, which was trying to protect its vested position as an exporter of petroleum products to Japan, even going so far as to protest against the plan to ban exports of crude oil to Japan, and by California-affiliated oil companies (such as Socal, Associated, and Union Oil), ${ }^{69}$ which persisted in trying to continue and expand their exports of crude oil to

${ }^{66}$ Mira Wilkins, "The Role of U. S. Business," in D. Borg and S. Okamoto, eds., Pearl Harbor as History (Columbia University Press, 1973), pp. 365-66; Irvine H. Anderson, Jr, pp. 78-79, 102, 198.

${ }^{67}$ The Sekiyu gyōhō kankei shiryō mentioned in note 36.

${ }^{68}$ Walter C. Teagle, Memorandum, August 21, 1934 (RG59, 894.6363/84).

${ }^{69}$ Memorandum, S. P. Coleman to E. J. Sadler, August 6, 1940 (Henry J. Morgenthau, Jr's Diary, vol. 292), pp. 268-70. 
Japan, the Japanese government is thought to have succeeded in this difficult task. The argument of Japanese researchers, who stress the loss of ground of the foreign oil companies under the Law, and that pf the foreign researchers, who emphasize the effectiveness of those companies' resistance to the Law, have each pushed one side of the truth, but the real truth lies in both sides.

\section{SUMMARY AND PROSPECT}

This essay has been, as pointed out in the very beginning, "one link in the operation of taking up typical foreign enterprises that have actually made a direct entry into Japan and expanded their business activities over a long period of time and adding a business-history study of them." Therefore, I would like to bring this essay to a conclusion by pointing out two perspectives that I think are important if this kind of operation is to be advanced hereafter.

The first is in a certain sense quite obvious: we must not direct our gaze only to events in Japan, but must have within our horizons the worldwide strategies and Asian strategies of the foreign enterprises we take up. In the context of this essay, unless we bring in such a perspective we cannot explain such issues as why Socony moved directly into Japan in 1893; why Socony established International Oil on such a grand scale in 1900; why Socony put all its efforts into forming a network of oil tank plants from 1909 onwards; why Socony allowed its position in the Japanese market to decline in the 1910s and 1920s; why Socony-Vacuum or Stanvac abandoned in 1934 the plan to build refineries within Japan that they began considering in 1932; and why from 1934 on Stanvac strongly resisted a decline in its share of gasoline sales under the Petroleum Industry Law.

The second perspective is, on the other hand, to pay careful attention to what is peculiar to Japan. In connection with this essay two things stand out as being peculiar to Japan that are noteworthy. One is the content of what should be called Japan's "medium advancedness," which shows its advancedness within the backward (as far as economic development goes) region of Asia. This "me- 
dium advancedness" manifested itself in the form of an increase in the demands for machine oils and gasoline that came later than it did in Europe and the United States, but earlier than it did in any other country in Asia, and in such things as being second to France in taking the lead in a policy of refining of imported crude oil. ${ }^{70}$ The reason why Vacuum opened a branch in Japan a step earlier than Socony is that it responded to a demand for spindle oil for the cotton-spinning mills and for other machine oils. Socony, on the other hand, failed to respond well to Japan's "medium advancedness." This is shown quite clearly by its late strategic response to the increase in gasoline demand, which led to the decline in its position in the Japanese market in the 1910s and 1920s; by its underrating the vitality of the refining of imported crude oil in Japan after the tariff amendments of 1926; by its hasty consideration in 1932 of a proposal to build refineries within Japan, which eventually did not materialize; and so on.

The second thing that ought to be pointed out as peculiar to Japan is the problem of anti-foreign industrial policies. Because of limitations in length I have not been able to touch upon this in this essay, but Japan's 1934 Petroleum Industry Law had an anti-foreign character to it by reason of the fact that, in contrast to the petroleum industry law of France upon which it was modeled, the government did not carry out any fine-tuning of opinions with the foreign oil companies in the process of framing the law; the fact that guarantees about the future in regard to any refineries the foreign oil companies built in Japan were insufficient; the fact that the government would not commit itself to taking into account the costs of the foreign oil companies when it established the official government purchase price of stock; etc. ${ }^{71}$ Also, it is an indisput-

${ }^{70}$ Iguchi, pp. 254-57.

${ }^{71}$ Letter, Kersey F. Coe (Stanvac) to J. C. Goold, November 19, 1934 (RG59, 894.6363/139); Memorandum of Conversation at Tokyo Club, January 9, 1935 (Class F. O. 262, British Embassy and Consular Archives, File Number 269 [1935], Part 4, kept in Public Record Office, Richmond, Surrey, U.K.). 
able fact that the actual application of the Petroleum Industry Law inevitably led to Stanvac's and Rising Sun's losing ground in the share of sales.

I also mentioned in the beginning of this essay that in recent years, in the debate over "opening" of the Japanese market, there is "opposition between those views that point out the substantial defects in foreign enterprises or foreign products, and those views that find fault with various unfair institutions existing in the Japanese market." I think it can be said that both of these aspects were found in the case I have taken up in this essay. 